\title{
Indian Textile Industry Possibilities Galore
}

\author{
Samir Agrawal ${ }^{1}$, Revathy Menon ${ }^{2}$ and NIsha Goel ${ }^{3 *}$ \\ ${ }^{1}$ Chief Strategy Officer, Arvind Ltd, India \\ ${ }^{2}$ Chief Manager-Corporate Strategy, Arvind Ltd, India \\ ${ }^{3}$ Deputy Director, Manufacturing Division at Federation of Indian, India \\ *Corresponding author: NIsha Goel, Deputy Director, Manufacturing Division at Federation of Indian, India \\ Submission: 制 March 06, 2018; Published: 望 March 21, 2018
}

\section{Introduction}

India is the second largest exporter of textiles and clothing in the world. The sector contributes over US\$ 30-35 B to India's exports; it is expected to increase to US $\$ 80 \mathrm{~B}$ by 2021 . Macroenvironment is favourable for exports with movement of apparel industry away from China, creating a potential market of over US\$ 280B for other supplying countries.

As our economy crosses the $\$ 2000$ per capita GDP mark, India is fast emerging as one of the largest consumers of apparels produced. Combined with China, the Asian apparel consumption will soon overtake that of the US and EU combined. This mega-shift will define the industry priorities for several years to come focus will certainly increase on domestic market and those in Asia.

There are multiple forces acting to shape the demand trends in the domestic market:

\section{Focus on fitness and sports}

Rising incomes and discretionary expenditure in urban India have allowed people to focus increasingly on health and wellness, mirroring the global trends. The at leisure segment is expected to be $\$ 3.5 \mathrm{~B}$, growing at a high $20-25 \%$ year on year, a rate faster than the rest of apparel categories. Functionality and performance are driving growth in higher end segments, shifting more towards MMF than cotton. Most national brands/retail formats have launched special active wear lines to capture this opportunity.

\section{Casual wear}

India is set to become the world's youngest country with $64 \%$ of its population in the working age group by 2020. It is also estimated that, by 2020 , almost $35 \%$ of the Indian population will be living in urban centres. This young and urbanizing population, with renewed confidence is continuing to drive the demand for less formal apparel

\section{Sustainability}

The clothing industry is the second-largest polluter in the world, second only to the oil industry," high-end retailer Eileen Fisher has famously said. From consumption of large volumes of water and chemical pesticides during cotton cultivation to discarded garments that end up in landfills, contribute to chemical pollution of the environment. With technology breakthroughs and design innovations, the focus on clean, sustainable fashion is stronger than it's ever been before. According to Indian Consumer Survey 7 in 10 Indian shoppers say they would be more likely to shop at a store offering clothes made from more sustainable materials, and nearly 8 in 10 (79 percent) say they put effort into finding sustainable apparel.

\section{Revival of local artisans}

India has a rich tradition of hand-woven textiles that has been drawing buyers from all over the world. According to the Ministry of Textiles, the handloom sector provided employment to 43 lakh persons. Ministry has introduced many measures including providing quality inputs, credit and market linkages. Private sector has also been contributing to government's efforts by pushing it in events and collections.

The apparel retail landscape is also witnessing a change in the country with the entry of foreign fashion retail such as Zara, H\&M and Mango. Top national brands are facing pressure to match up to the fashion offerings by these brands. In the meanwhile, lower end of the retail spectrum is also getting formalised. With GST mandating transparency on transactions, and proliferation of value retail formats in Tier 3 \& 4 cities, the unorganised sector is feeling the pressure to stay alive. Fashion garments with value for money promise is increasingly building a strong hold on the semi-urban customers. Online portals also are a force to reckon with Myntra claims that they have serviced $>90 \%$ of the 19,100 pin codes in India.

On the supply side as well, the Indian textiles and apparel industry is grappling with multiple challenges:

\section{Competitiveness to apparel imports}

India has imported $\$ 87.4$ million worth of readymade garments from Bangladesh during July-November 2017, registering a sharp 
rise of $56 \%$ compared to that during the same period last year. PostGST regulations, there is no cost/duties for importing garments from Bangladesh, rendering domestic vendors vulnerable. It is an imperative to recapture the domestic market through innovative business models/out of the box execution strategies.

\section{Digitisation of the value chain, use of big data/AI}

Digitisation of end-end value chain, generation of data and advanced technology, have opened the door to the use of big data and analytics. Customer insights are generated and worked backwards to align all partners and identify business opportunities across the value chain. Eg. Dynamic pricing, optimised product replenishment, etc.

\section{Integrated and responsive supply chain}

With integrated supply chain partners and technology enabled forecasting of trends and optimum volumes, the supply chain partners need to evolve to a fully vertical, design to delivery model. This is crucial to servicing the customer market where trends spread at lightning speed thanks to social media and global sociocultural integration

For the Indian textiles and apparel industry, the possibilities have never been more exciting. Even though there are several challenges, the visible and emerging trends promise a world full of opportunities.

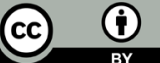

Creative Commons Attribution 4.0 International License

For possible submissions Click Here

\section{Submit Article}

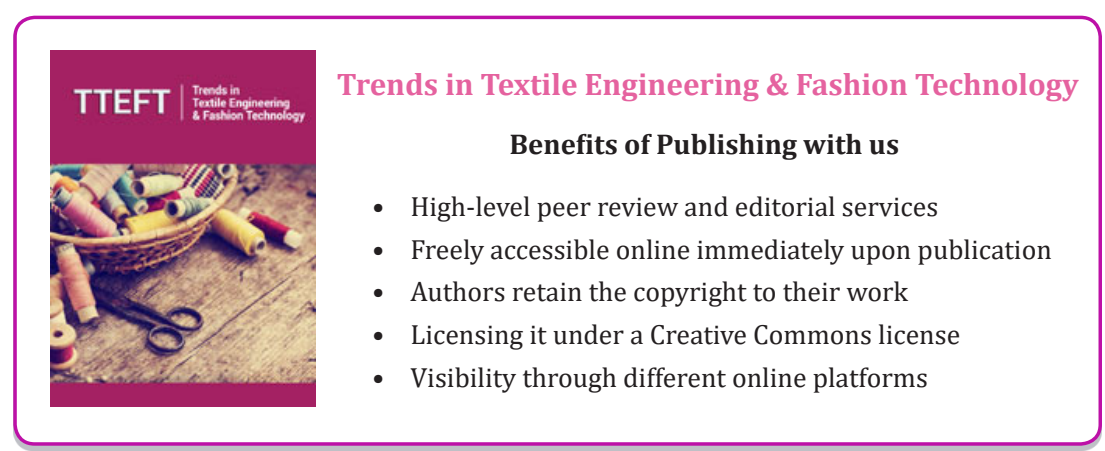

